\title{
Some Highland Folklore
}

\section{W. A. Craigie}

To cite this article: W. A. Craigie (1898) Some Highland Folklore, Folklore, 9:4, 372-379, DOI: 10.1080/0015587X.1898.9720475

To link to this article: http://dx.doi.org/10.1080/0015587X.1898.9720475

曲 Published online: 14 Feb 2012.

Submit your article to this journal

Q View related articles $₫$ 


\title{
The Nibrlung Treasure in English.
}

References to the Nibelung story are not frequent in early English literature, and they are all old (Beowniff, Widsith) except possibly a reference in Sir Degrevant, which has apparently not jet been noticed:

\author{
$Y$ hade leve she were myne \\ Thane alle the gold in the Regne \\ ffausoned one florene, \\ She is myne so dere.
}

\section{-Sir Degreoant, L. 525 sq. (Thorinton Romances,} ed. J. O. Halliwell, Camden Society, 1844.)

The gold of Rhine can hardly be anything but the hoard of the Nibelungs. How it came down to a fifteenth-century English scribe, whether by continuous tradition from the old times or by later communication with Germany, may be left as a problem.

W. P. KER.

\section{SOMr Highiand FoLkLORE.}

In the spring of 1896 I received from a native of Farr, Sutherlandshire, a few notes on some traditions of the district, "told by most respectable and trustworthy people-stories which they said came under their own observation." Finding that two or three of these were fairly interesting, I afterwards got him to tell them over in Gaelic, which I took down at the time, retaining as far as possible the peculiarities of his dialect. As so little has been done in the way of printing local Gaelic, I append some of the originals to the English translations.'

1 Those acquainted with Gaelic will notice considerable uncertainty with regard to the forms of come words, this is due to the speaker himself, who may have been trying at times to conform his dialect to the usual literary atandard. It will also be noticed that a principle akin to eclipsis in Irish, 
Dreams, ghosts, and second-sight are the subjects chiefly illustrated in these notes. I do not know that there is much that is new in them, but they have the merit of being quite genuine, and from an out-of-the-way district.

\section{I.-The Labourer's Dream.}

A labourer (nawry) was working on the road between Rhi-conich and Durness, in Sutherlandshire, about fifty jears ago, and dreamed on a Saturday night that if he rose early on Monday morning, so as to be at Carn Glas at sunrise, he would see a crow sitting on a stone. Under that stone he would find the gold which was hid after the murder of a Norwegian prince.

The labourer was in so great a hurry to get the gold that he could not wait till Monday, but set off on Sunday evening, as be had a long way to go. When he reached Carn Glas, there was a crow sitting on a stone, but he did not know which was the right one, for there was a crow on every stone !

People who could interpret dreams said that this bappened because he broke the Sabbath; he ought to have waited till the Lord's Day had gone past, and he would have been certain to get the gold.

quite lgnored by Scottish grammarians, appears in a number of cases. This in a feature of many Scottish dialects, but the cased in which it cocurs are not quite the same as in Irish: it is found, for example, in the nominalive singular (as an d-tarbh, the boll). Some dialects go further than this, and make the eclipsis stand for the article itself (as fear, a man i bh-fear, the man).

\section{- Brwadar far-abrack.}

Bha fear-obrach 'g oibear air an rothad eadar Ruidh Chonaich agus Diurinin anns Catrobh, mu leth-chend blian' air ais, agus bhruadraich e air eluhch' Di Sathnirn', na'n eirich e tráth air muchthra' Di Luain, chum as gum biog e ig Carn Glas mu's eirich a' ghrian gum faiceag e rocals 'n a suidh air clach. Fo'ne chlach sin gheibh $e$ an d-6r 'bha air 'fhalach an deigh bpriu(nn)a Loch. lannach 'bhi air a mhort.

Bha leud do chabhaig air an fhear-obrach air son an d-br fhaotainn 's nach W' urrainn e fanuidh gu Di Luain 's dh'fhalbh e feasgar ma Sabaid, oir tha astar fhad aig' ri thol. Air ruigsinn Carn Glas, bha rócais 'n a suidh air a clach, ach che robh fhios aif' dé 'chloch cheart, air bha rocais air a h-uilo clach.

Thuirt muinntir b' urrainn bruadair 'leughadh gun do thachair 50 a chionn guin do bhris e an t-Sabaid, bu chóir da bhi air fantainn gus en deach la an d-Tighearn seachad, agus bhiodh e cinnteach as an d-ór thaotainn. 


\section{II.-The Sailor's Ghost.}

A few years ago there was a certain man living in the parish of Durness, in Sutherland, close to the sea, where ships were very often lost. This man found some things belonging to a ship that. went to pieces on the rocks, and took them home with him. A night or two after this, what came but a ghost in the dress of a sailor, which walked back and forward through the house; and after a long time disappeared from sight. Next night the ghost returned, and kept throwing the furniture here and there. Each night it stayed longer than on the night before, and was always growing bolder.

The poor man was in great fear; he thought that it came after the things he had taken from the beach, but he had so many of these that he did not know which of them the ghost wanted. He went to the minister, who advised him to rise when the ghost came again, and to ask of it what it wanted. This was a difficult matter, for people believed that if any man spoke to a ghost he would not live long after it. Finally, the man had to summon up courage and ask the ghost for what reason it kept coming to his house. The ghost answered by pointing with its finger to the door, and asking the man to walk with it towards the beach. - He did so, and they talked together all the time until they came within view of the sea, when the ghost disappeared and caused no more trouble to the house.

The man returned home and went to bed, after reading his Bible. He refused to tell what had happened between himself and the ghost, but if they asked him on his death-bed be would tell them all that had taken place. Those who were round his death-bed had not the courage to ask him, and never got to know what had happened between them. This man was alive many years after talking with the ghost, and when he died he was an old man, which showed that there was no truth at all in what people think, that a man would die if he spoke with a spirit.?

\section{- Taisg an drebt dair.}

Teirc' do bhlianachan air ais bha duine araidh bed anns sgire Dhiurinis anns Cataobh fagas air a' mbXir, far an robh saoitheachá ǵ minic air an g-call. Fhuair an duin' so nichean a bhunuidh do sheathach cha' na smurach air na cragan, agus thng $e$ leis dhachaidh iad. Eidhch' no dha an deigh 20 , gui d'E thainig ach tsigg ann an aodudh sebl'dair; agus bha e dol cir ais agus air 


\section{III.-The Corpse on the Man's Back.}

There is a man, still alive, in the parish of Durness, who has the second-sight. He has seen and heard many wonderful things -lights, coffins, funerals, knocks, and the cries of people drowning. One night he and a neighbour were coming home very late. They took a short cut and came along by the side of a small bay. While they were passing this, the man gave a great pant, as if a heavy burden was being thrown on his back. His companion asked what was the matter with him. He replied: "Man, did you not see that body rising upon my back ?" The other man ran away, crying: "I shall never go with you again after nightfall"

- A short time after this, a vessel was lost on the beach and all hands were drowned. One of the bodies came ashore in this same bay, and in order to get it to a place until a coffin could be made for it, the corpse was lifted upon this man's back at the very spot where he felt it coming on his back before. When the body

aorthart troimh an d-taigh, agus an deigh tin' thad, cha' e as an d-cealladh. Thainig an d-taisg air ais an ath-eidhch', agus bha e tuilgeil an fhú(r)naist fiar agus a fiar. Bha $e$ fanaig na h-uile h-eidhch' na b' theid' no 'n eidhch' roimh', agus tá na 's láda(r)n'.

Bhe eagail ro-mhor air an duine bhochd 8 smaointich 0 gur ann a tóir me nichean a shlaod 00 'na chladach, ach bha uiread 'ig' agus nach robh fios aig' go d't ni a bha an d-tóng ag iarraidh. Chaidh e dh' lunns' a' mbinisteir, agus cho'irlich exan dha, eireadh nuair thigudh an d-tásg 'rithist, agui fheighneachd dhe gu d' $\ell$ bhs $f$ ' $g$ iarrailh. Bha so ro-dhuilich, oir bha an sluagh creidsinn nam bruighnuidh fear sam bith $t$ t teng nach biodh $e$ fad beo an dinigh tin. Fadhebidh bhe aig an duin' ri aghaidh chuir air, agus theigneachd ris an d-táng gu d't 'n aobhar bh'aig, esan tighinn dh' iunnsaidh an taigh aig. Fhreagair an d-tasg agus chumasaich $e$ 'mheur a dhiunneai' an doruin, agus dh' theorraidh $e$ an duin' coisidheachd maille ris a dh' iunnsaidh a' chlaclaich. Rinn an duine so, agus bhe iad labhai(r)st ri cheile fad na h-liin, gus an d-tainig ind am fraodhraig na mara, nuair cha' an d-tísg as an d-realladh, agua cha do chuir c trioblaid tuille air an d-taigh.

Phill 'n duine dhachaidh, agus an deigh dha a' Bhiobull 'Jeughag, cha' e a laidh. 'Dhiult e inniseag gu d'E thachair eadar cis' agus an d-tśsg ach na feóraicheadh lad e air léabaidh bhdis, dh' inniseag e na h-uile ni 'thachair. Cha robh misneach aig a mhuinntir, 'bhn timchioll air leabaidh bhais, 'Theighneachd dhe, agus cha robh riamh fios ac' gu d'e thachair eadar 'ad. . Bhn 'n duine so beo moran bhlianachan an deigh 'bhil labhairt ris an d-tágg, agus nuair chaochail - bha e 'na sheann-duine, agus bha sin 'fiachainn nach e ni air bith do dh' Mirian anns an ni tha muinntir a smaineachag gum faigheag duin' bais nam bruidh. neamh e ti spiorad. 
was lifted on his back, the man gave the same sort of pant as before. His neighbour, who was present, remembered what had happened when they were coming home late.1

Some other illustrations of second-sight come from the same source, and I give them, as far as possible, in the narrator's own words.

IV. "In one parish in the North, two men were out fishing when the boat capsized and both were drowned. One of the bodies was recovered, the other not. Several days after, a man in the parish dreamed that the body was to be got in a certain creek. In the morning he went off to search for it, and on his way met two men, to whom he told his dream. They followed him, and found the body at the place which he had spoken of."

$V$. "In the West Highlands, where I was last summer, the people of the district have been advocating for a railway for many years. I remarked to one of them, that it looked as if they were not to get it. 'It looks doubtful,' said he, 'but we will get it yet: I am sure of that.' 'How are you so sure?' I asked. He said, that he and and another man were walking along the road in the dark, when they both saw, quite distinctly, a train passing them, and even observed it puffing."

VI. "A man from our parish was working near Bonar Bridge before the railway went north. He and a friend were returning

\section{An E-corp air druim duine.}

Tha duine beo fathast an sgir' Dhiúrnis aig am beil fiosaidheachd. Chunnaic agus chuala e lomudh ni lo(ng)antach - solasan, cistean-laidh', tiodhlacan, grogadaich, agus eibheachd muinntir air am bathag. Bha efhein agus nábuidh tighinn thachaldh gle anamoch aon eidhch'. Ghath lad rothad goirid, agus thainig lad reachad a taobh baghach beag. Air dhaibh bhi dul reachad air eo, thug an duine ialt mhorr, mar gum biog eallach trom air a thilgeil air a dhruim. $\mathrm{Dh}^{\prime}$ fheighneach a chompanach dhe gu d'e bha cur air. Fhreagair cis': "Dhuine, nach fhac" thu an g-corp sin aig eireadh air mo dhruim ?" Ruith an duine eile air falbh ag eibheachd: "Cha d-teid mis" gu brath trille maille ruits' an deigh 'n eidhch' tuitim."

Uine bheag an deigh so, cha' seathach 'chall air a chladach, agus cha' na lamban uile a bhathag. Thainig aon do na chorpan air tir anns $\alpha^{\prime}$ bhaghiach so, agus chum us gu feigheag iad e gu ait gus an de'ag a chist laidh 2 dheanaig, cha' en g-corp a thogail air druim an duine so, direach anns an fit far an $\mathrm{d}^{*}$ fhoireach e corp tighinn air a mhuin roimhe. Nuair cha' an g-corp thogail air a dhruim, thug an duine an ionn' stors' ialt agus a thug e roimhe. Chuimhnich a nibuidh, "bha ann an sin, an ni a thacheir nueir bha lad tighinn dachaidh anamoch. 
home one night when they distinctly saw a train proceeding along the present route; they could hear the noise and see the smoke. This happened many years before the train came to Inverness."

The following is perhaps noticeable among dream-stories, from the fact that it led to nothing, notwithstanding the recurrence of the dream at regular intervals.

VII. "There lived an old woman at Durness, who dreamed one night that under a certain stone at Inshore, near Cape Wrath, there was a pot of gold concealed, which she would find by digging under the stone. She went to the place, but found no treasure.

"Exactly twelve months after, she had the same dream, and again went to the place, accompanied by a shepherd. They removed the stone, but found nothing.

"Another twelve months went past, and again she had the same dream. She returned to the spot, and searched all round the stone, but could find no trace of the gold. This woman was well known in the place by the name of 'Iuraidh Sir' (Gold Dorothy). She dreamed no more about the treasure."

The next tale is a fairly common one in Scotland, but it may not be amiss to give it in its Sutherland form :

VIII. "One time a corpse was laid out in a room, and the watchers had retired to another apartment to partake of some refreshment, shutting the door of that in which the body lay. While they were eating they heard a great noise in the room where the body was; no one would venture in to see the cause of this, and they finally sent for the minister. He went in, Bible in hand, and closed the door after him. The noise then ceased, and in about ten minutes he came out, lifted the tongs, and went back to the room. On his return he held in the tongs a glove, which was seen to be bloody, and put it into the fire. "He would not tell them what he had seen and heard."

To these Sutherland legends I may add a few scraps from other quarters of the Highlands. The following was told me by a native of Glenlyon, who admitted that he was no lover of folklore, and professed to have forgotten all the stories that the old people used to tell.

"There is a pool in Glen Dochart in which people who had gone out of their mind were dipped, and it was believed that this was a 
means of restoring them to their senses. Near this pool lived 2 farmer who had a bull that went mad : he put it into the pool, but after this the water lost the effect that it previously had."1

The same informant spoke of a method of curing illness in horses by means of water taken "from under a bridge where the dead and the living cross." He either did not know or did not care to give the full particulars; a silver coin was put into the pail, and if this stuck to the bottom when the water was poured out, the horse's illness was at once ascribed to witchcraft (compare Frolk-Lore, 1897, p. 92). An old Highlander, resident in Stirling, told my brother how his daughter's child was cured from the effects of the Evil Eje by giving it warm water to drink, into which nine pointed iron instruments had been dipped. After the cure had been effected the old man asked his daughter where she got the water. "Did you go down to the bridge for it?" "No, indeed," said she, "I just took it out of the pipe; aren't the dead and the living going down the street every day?" This is how folklore is adapted to modern conditions.

From a native of Skye I have two stories, which are perhaps worth recording as a contrast to the more serious side of popular belief. The one is of a man who was passing a churchyard by night, when a ghost came out and blocked his way. Thinking that it was likely to attack him, he gave it a word of warning: "You had better not lay hands on me," he said; "I have as many friends in there as you have" The other represents the triumph of the sceptic over the believer. A young fellow told his companions how he had looked over a rock into the waters of a lake, and had seen the river-horse lying asleep. "What was it like?" they asked. "Well, it was just like a big ass." "Oh," said one, "it had been your own shadow, man."

It is very much to be desired that persons possessing a thorough knowledge of the Gaelic dialects in the various localities would devote some time to recording the folklore of their districts. While the fairy-tales have received a good deal of attention since Campbell's day, very little has been done to preserve the many

I Tha linn ann an gleann Dochairt anns an robh muinntir bhe air dol thar a chéill 'gan tume', agus bhe iad creidsinn gun robh so 'n a mheadhon ( $x^{*} n$ ) air an toirt $g u$ 'm beachd. Bhe tuathanach fagus air an linn sin alg an robh tarbh 'chaidh air chrothach; chuir e'n d-tarbh anns an linn, ach an deigh sin cheill an d-uisg' an eibheachd 'bha ann (Kawn) roimhe sa. 
stories of ghosts, witches, fairies, \&c, exactly as they exist in popular tradition. We have many essays and articles on "Highland Superstition," but most of them have the fault of being too general, or of giving their illustrations in a form that is hardly original. The tales ought always to be taken down in the exact words of the speaker, especially as many Highlanders are excellent narrators of such stories. Not only would such collections be of great service to Celtic students, by giving genuine specimens of various dialects, but they would in time form a body of Highland folklore which might stand favourably in comparison with that of other countries, with Jon Árnason's two volumes of Icelandic tales, for instance, or E. T. Kristensen's many publications in Danish. Gaelic folklore cannot but suffer if it is only given in English forms, and half-a-dozen willing workers would not be long in covering the greater part of the ground. It is well, too, that the work should be done very soon, before printed sources have vitiated local tradition, as they have done in several districts already.

W. A. Crascir

\section{Thr Black Lad of Ashton-Under-Lyne}

[Dr. TrLor has been good enough to forward the following letter addressed to him by Mrs. F. H. Griffith, of Riversvale, Ashtonunder-Lyne, together with the notes appended.]

Drar Dr. TyLor,

Herewith are what I promised you: all the facts relating to the immemorial custom of "Riding the Black Lad" in Ashton: under-Lyne on the afternoon of Easter Monday, which I was able to gather in 1895 from old people, upwards of eighty years of age, who could tell me something of the practices prevailing before the outrageous proceedings connected with this rite were suppressed about 1830 or 1832 . Each assured me that everybody connected with the rites was "very low," that the whole thing had been "a disgrace to the place," and some added that "the sooner such things were forgotten the better." . So my informants, being all "decent folk," had never been allowed by their parents and guardians to take part in the performances. -

All the answers which I could get to all my questions I hive in writing; in the notes I send you the data are sifted and chassificd. At the present day several Black Lads are ridden round the 